\title{
Intellectual Property and Pharmaceutical Prices in the United States
}

\author{
Gilbert Berdine $M D$
}

Pharmaceutical are big business. World sales of pharmaceuticals were estimated to be $\$ 903$ billion in 2014. U.S. sales were $\$ 365$ billion of that total. ${ }^{1}$ Pharmaceuticals have become sufficiently unaffordable in the U.S. that Medicare was expanded to include a prescription drug benefit called Part D. In calendar year 2013, Medicare part D had 39.1 million beneficiaries and spent $\$ 69.3$ billion in benefits for an average annual benefit of $\$ 1,773 .^{2}$ Pharmaceuticals are highly regulated and the trade of pharmaceuticals is highly restricted such that large differences exist for similar or identical products in different parts of the world. This article will examine these price differences and the mechanisms responsible for them.

\section{Table 1}

\section{International Drug Prices: Data}

\begin{tabular}{llrlll}
\hline Name & Generic & Dose & Online & NHPrice & Ratio \\
\hline Nexium & Esomeprazole & $20 \mathrm{mg}$ & 0.42 & 6.27 & 15.108 \\
Lipitor & Atorvastatin & $10 \mathrm{mg}$ & 0.44 & 3.31 & 7.523 \\
Plavix & Clopidogrel & $75 \mathrm{mg}$ & 1.17 & 5.88 & 5.026 \\
Advair & Salmeterol & $250 / 50$ & 1.01 & 3.53 & 3.495 \\
Oxycontin & Oxycodone & $10 \mathrm{mg}$ & & 2.50 & \\
Abilify & Aripiprazole & $5 \mathrm{mg}$ & 0.59 & 17.16 & 29.333 \\
Singulair & Montelukast & $10 \mathrm{mg}$ & 0.94 & 4.34 & 4.617 \\
Seroquel & Quetiapine & $25 \mathrm{mg}$ & 0.39 & 2.94 & 7.538 \\
Crestor & Rosuvastatin & $5 \mathrm{mg}$ & 1.17 & 4.33 & 3.701 \\
Cymbalta & Duloxetine & $20 \mathrm{mg}$ & 0.59 & 4.47 & 7.641 \\
Actos & Pioglitazone & $15 \mathrm{mg}$ & 0.40 & 41.0 & 13.525 \\
Lexapro & Escitalopram & $5 \mathrm{mg}$ & 0.39 & 3.22 & 8.256 \\
Zyprexa & Olanzapine & $10 \mathrm{mg}$ & & 16.25 & \\
Spiriva & Tiotropium & $18 \mathrm{mcg}$ & 1.01 & 7.25 & 7.178 \\
Lantus & Insulin & $100 / \mathrm{ml}$ & & 10.03 & \\
Aricept & Donepezil & $5 \mathrm{mg}$ & 1.17 & 8.89 & 7.598 \\
Lyrica & Pregabalin & $100 \mathrm{mg}$ & & 2.63 & \\
Diovan & Valsartan & $80 \mathrm{mg}$ & 0.89 & 2.39 & 2.685 \\
Effexor & Venlafaxine & $75 \mathrm{mg}$ & 1.27 & 4.86 & 3.827 \\
Levaquin & Levafloxacin & $500 \mathrm{mg}$ & 0.64 & 17.31 & 27.047
\end{tabular}

Corresponding author: Gilbert Berdine MD Contact Information: Gilbert.Berdine@ttuhsc.edu DOI: $10.12746 /$ swrccc 2015.0311.142
Table 1 lists drug prices in 2011. The drugs were chosen as the top drugs by U.S. dollar volume. Online prices were obtained using Google. New Hampshire prices were used as a proxy for U.S. prices since New Hampshire had online listing of pharmaceutical prices available in that state that were sortable by drug and price. Not all of the drugs were available online due to narcotic or other restrictions. For all the drugs available outside of the United States as a generic equivalent, U.S. prices were higher than prices outside the U.S. The largest disparity was for Abilify with the U.S. form costing over 29 times the world price.

Table 2 lists current drug prices. The drugs were chosen by top U.S. dollar volume. The most recent data is for the 4 th quarter $2013 .{ }^{3} \mathrm{U}$.S prices were obtained using GoodRX.com and included a so-called "free" coupon. ${ }^{4}$ Retail prices in India were obtained from Ambe Medical Store in Vadodar, Gujarat, India. As was the case for Table 1, not all the drugs were available in India (OxyContin) or the formulations are for different strengths or number of doses (Advair). The two tables provide illustrative examples. Abilify went from $\$ 29.33$ to $\$ 30.23$ in the U.S., but it is available in India for less than 1c per tablet. The ratio of U.S. price is over 3,000 times that of the India price. The largest price disparity was for Rituxan which costs $\$ 732$ per dose in the U.S. and is available as rituximab for less than 12c per dose in India. One drug, Diovan, was on both lists, but it went generic in the U.S. since the drug ranking in Table 2 was published. Diovan was sold for $\$ 2.69$ in 2011 and valsartan is sold in the U.S. for $\$ 0.66$ today. In fact, valsartan is less expensive in the U.S. than in India, the only drug in Table 2 with that distinction. Other top sellers from 2011 were no longer top sellers (by USD volume) in 2013. This is due to brand name drugs becoming generic drugs in the U.S. Examples include Lipitor which is now sold as atorvastatin. Plavix has an interesting history and will be discussed separately. 
Table 2

\begin{tabular}{|c|c|c|c|c|c|c|}
\hline Brand Name & Generic Name & Dose & GoodRx Price (Coupon) & India Price (rupee) & India Price \$/tablet & US/India \\
\hline Abilify & ARIPIPRAZOLE & $5 \mathrm{mg}$ & 30.30 & $5.40(10 \mathrm{mg})-10$ tablets & 0.008 & $3,647.18$ \\
\hline Nexium & esomeprazole & $40 \mathrm{mg}$ & 3.43 & $30(40 \mathrm{mg})-10$ tablets & 0.046 & 74.22 \\
\hline Humira & adalimumab & $40 \mathrm{mg}$ & 1481.27 & & & \\
\hline Crestor & rosuvastatin & $10 \mathrm{mg}$ & 7.20 & 115.8 (10 tablets) & 0.178 & 40.40 \\
\hline Advair & $\begin{array}{l}\text { fluticasone and } \\
\text { salmeterol }\end{array}$ & $\begin{array}{r}250 / 50 \\
\mathrm{mcg}\end{array}$ & 309.00 & & & \\
\hline Enbrel & etanercept & $50 \mathrm{mg}$ & 737.85 & & & \\
\hline Cymbalta* & duloxetine & $60 \mathrm{mg}$ & 0.93 & 125 - 10 capsules & 0.192 & 4.85 \\
\hline Remicade & infliximab & $100 \mathrm{mg}$ & 991.56 & & & \\
\hline Neulasta & pegfilgrastim & $6 \mathrm{mg}$ & 4740.15 & & & \\
\hline Copaxone & glatiramer & $40 \mathrm{mg}$ & 422.18 & & & \\
\hline Lantus & $\begin{array}{l}\text { Solostar insulin } \\
\text { glargine }\end{array}$ & $3 \mathrm{ml}$ & 79.20 & & & \\
\hline Rituxan & rituximab & $100 \mathrm{mg}$ & 732.00 & 7.65 & 0.118 & $6,219.61$ \\
\hline Spiriva & tiotropium & $18 \mathrm{mcg}$ & 10.30 & 150 - 30 capsules & 0.077 & 133.85 \\
\hline Januvia & sitagliptin & $100 \mathrm{mg}$ & 11.40 & $315-7$ tablets & 0.692 & 16.47 \\
\hline Atripla & $\begin{array}{l}\text { efavirenz, emtri- } \\
\text { citabine, and } \\
\text { tenofovir }\end{array}$ & $\begin{array}{l}600 \mathrm{mg} / \\
200 \mathrm{mg} / \\
300 \mathrm{mg}\end{array}$ & 74.83 & 807 - 30 capsules & 0.414 & 180.82 \\
\hline Lantus & See \#12 & & & $801.03(100 \mathrm{lU} / \mathrm{ml})$ & & \\
\hline Avastin & bevacizumab & $400 \mathrm{mg}$ & 2749.97 & 115(20mg) & 1.769 & $1,554.33$ \\
\hline Lyrica & pregabalin & $75 \mathrm{mg}$ & 4.98 & 842 - 14 tablets & 0.925 & 5.39 \\
\hline OxyContin & oxycodone & $20 \mathrm{mg}$ & 5.21 & & & \\
\hline Epogen & epoetin alfa & $10,000 U$ & 154.28 & & & \\
\hline Celebrex & celecoxib & $200 \mathrm{mg}$ & 2.27 & 130.90 - 10 capsules & 0.201 & 11.29 \\
\hline Truvada & $\begin{array}{l}\text { emtricitabine } \\
\text { and tenofovir }\end{array}$ & $\begin{array}{l}200 \mathrm{mg} / \\
300 \mathrm{mg}\end{array}$ & 46.18 & & & \\
\hline Diovan & valsartan & $160 \mathrm{mg}$ & 0.66 & 1506 - 24 tablets & 0.965 & 0.68 \\
\hline Gleevec & imatinib & $400 \mathrm{mg}$ & 310.36 & 1800 - 6 tablets & 4.615 & 67.24 \\
\hline
\end{tabular}

\section{Prices and Free Markets}

Price differences can and do exist in a free market. The cost of steak is quite different at the Café of the Americas than at the corner butcher shop. These differences are due to differences in quality, service, and ambiance which clearly have value to customers. Differences in fungible items can also exist, but they are limited to the cost of transport. If a tablet costs 1 cent in India, and the same tablet costs $\$ 30$ in the U.S. and the cost of transport is small, then someone will buy tablets in India, transport the tablets to the U.S., and sell the tablets in the U.S. at a huge profit. If these huge price differences persist for more than a short period of time, it is an absolute certainty that some agency is impairing or preventing the free flow of goods from place to place. In the case of pharmaceuticals, that agency is the U.S. government.

\section{Intellectual Property}

Why does the U.S. government act in such a way to make U.S. citizens pay 6000 times the price for a pharmaceutical tablet? The U.S. has patent laws that grant monopoly privilege to owners of patents. The U.S. government vigorously enforces these laws. These laws are not recognized elsewhere in the world. The government of India, for example, does not recognize U.S. drug patents. Who is correct? Is the government of India harming U.S. patent holders? Or is the U.S. government harming its own citizens?

There is a concept known as Intellectual Property or IP for short. The U.S. government has extended property rights to ideas. The U.S. mainstream views these rights known as patents, copyrights and trademarks as a boon to innovation. It is deemed nec- 
essary for innovation to reward the creators of new ideas with monopoly profits. In the pharmaceutical business, IP is also deemed necessary to overcome the large regulatory burden placed on new drugs by the FDA.

\section{Critique of IP}

The political left is associated with both egalitarianism and socialism, so the left is generally opposed to the government grant of monopoly profits to drug manufacturers in the form of patents. The political left sees the public benefit of low prices for pharmaceuticals as taking precedence over property rights.

The political right views social stratification as either inevitable or desirable. Different elements of the political right support IP for different reasons. Limited government conservatives believe that ideas are property and should be protected as such in the same way the property rights exist for tangible property such as land, houses and automobiles. Authoritarian conservatives support the use of government power to benefit a privileged few. An alliance is created between a corporate oligarchy and political agents which exchanges barriers to competition against the privileged few for campaign contributions. This is known as rent seeking behavior. The extreme form of this alliance is called fascism.

Some libertarians believe that IP is an inappropriate extension of property rights to ideas which are not property and cannot be considered analogous to property. These anarcho-capitalists are the strongest supporters of property rights, profit and capitalism, but they view IP as government monopoly rather than enforcement of economic rights; they oppose IP because ideas are not property. ${ }^{5}$

Property has a characteristic of exclusion. This means that only one person can use the property at one time. The use by one excludes others from simultaneous use. If property rights do not exist, then people fight over control of valuable resources. Civilized communities develop codes of normative be- havior which is known as common law. This common law includes recognition of ownership and penalties for theft.

Many adults have owned a car at one time or another. If the car were stolen, how would the owner be aware of that fact? When the owner tried to use the car to travel from one place to another, it would no longer be available for use. The thief has harmed the owner by virtue of preventing the owner from enjoying what is rightfully his.

Now, consider a piece of paper with a circle drawn on it. The paper is clearly property. The physical drawing is clearly property, but the idea of the circle is not property. If someone else made his own circle or sphere and used it to make some gadget such as a hula hoop or a ball bearing, he would not have stolen anything from me or anyone else. The use of the circle idea by someone else does not impair me in any way from creating anything that uses the circle. Since ideas do not have the characteristic of exclusion, there is no need to grant them property rights.

Indeed, IP leads to some ridiculous results. Suppose two people completely independently developed an idea. Such has happened many times. An example would be the calculus developed independently by Leibnitz and Newton. It would be ridiculous to claim that Newton stole the idea from Leibnitz, or vice-versa, merely because some government agency granted one of them a patent.

Colchicine offers an example of this type of ridiculous result. Colchicine has been used to treat gout since ancient Egypt in 1500 BC. In June 2006 the FDA announced the Unapproved Drugs Initiative designed to regulate drugs that were in common use prior to the regulation of new drugs by the FDA in 1962. ${ }^{6}$ URL Pharma was granted monopoly privilege to sell colchicine under the brand name Colcrys in the U.S. URL Pharma did not develop anything; all the company did was test Colcrys against placebo in 184 patients. ${ }^{7}$ The price of colchicine went from around 10c per dose to over $\$ 5$ per dose. Today, GoodRx 
shows the least expensive source of colchicine to be $\$ 81.49$ per 30 capsules with a so-called "free" coupon for a price of $\$ 2.72$ per capsule. The Walmart price is $\$ 4.48$ per capsule (with so-called "free" coupon). The current price in India is 12 rupees for 10 capsules or 1.8 cents per dose in USD.

\section{Medical Tourism}

U.S. patent law and the monopoly pricing of pharmaceuticals have created a whole new industry: medical tourism. Medical tourism occurs when a U.S. citizen travels to a foreign country for the purpose of obtaining health care at a lower price. One form is to obtain less expensive pharmaceuticals.

Plavix offers a well-known example of medical tourism. In 2011 the drug Plavix was available in the U.S. for over $\$ 5$ per tablet. The maker of Plavix was offered a choice by the Canadian government: either sell Plavix to the Canadian health service at a much reduced price, or Canada would permit one or more generic manufacturers to produce the drug in Canada. So the American made tablets were shipped to Canada, placed in a different box, and sold to Canadians for $1 / 3$ the U.S. price. This price disparity created online pharmacies that existed primarily to sell Canadian Plavix to U.S. citizens. To enforce the monopoly privilege at the expense of U.S. citizens, the U.S. Customs Service cracked down on the transport of Plavix from Canada into the U.S. under the pretext of the war on terror. If a U.S. citizen purchased the Plavix in Canada and returned it to the U.S. he would be in danger of having the Plavix confiscated by U.S. Customs agents in their war on terrorism.

Do patents encourage innovation? The historical record suggests otherwise. 5 Patents tend to encourage litigation over what constitutes breach of patent, and innovation becomes stalled until the patent expires. Monopolists have no incentive to offer an improved product at a lower price. A patent relieves a manufacturer from the burden of the market to ever improve one's product at ever lower prices to consumers. The most notorious case may be the patent or trademark on Mickey Mouse which has been extended to over 75 years.

Do we have drugs with U.S. patents that we would not have otherwise? We probably do, but the question is at what cost. This is an example of what the French economist Frederic Bastiat called "what is unseen." A patent is a subsidy to the pharmaceutical company in the form of monopoly privilege. Like all subsidies, we have higher quantity at higher price. The problem is that people would rather have some other thing that they cannot have due to the cost of pharmaceuticals and these other things are the unseen costs of patent protection. Do we really want or need drugs that are so expensive that the new entitlement of Medicare Part D was required to make them affordable?

Author Affiliation: Dr. Gilbert Berdine is a pulmonary physician in the Department of Internal Medicine, TTUHSC.

Published electronically: 7/15/2015

\section{References}

1. http://www.statista.com/statistics/272181/world-pharmaceutical-sales-by-region/

2. http://www.cms.gov/Research-Statistics-Data-and-Systems/Statistics-Trends-and-Reports/ReportsTrustFunds/downloads/tr2014.pdf

3. http://www.drugs.com/stats/top100/sales

4. http://www.goodrx.com/

5. https://mises.org/sites/default/files/Against\%20Intellectual\%20Property_2.pdf

6. http://www.fda.gov/Drugs/GuidanceComplianceRegulatoryInformation/EnforcementActivitiesbyFDA/SelectedEnforcementActionsonUnapprovedDrugs/ucm118990.htm $7 . \quad \mathrm{http}: / / \mathrm{www}$.slate.com/articles/health and science/medical_examiner/2011/03/a_giant_pain_in_the_wallet.html 